\title{
Evaluasi Penggunaan Antibiotik pada Pasien Pasca bedah Apendisitis Akut di RSUD Kabupaten Pasuruan Tahun 2018 (Penelitian dilakukan di Instalasi Rawat Inap RSUD Kabupaten Pasuruan)
}

\author{
Wirda Anggraini $^{1}{ }^{*}$, Novia Beta Wiraningtias ${ }^{1}$, Fidia Rizkiah Inayatilah ${ }^{1}$, Yen Yen Ari Indrawijaya ${ }^{1}$ \\ ${ }^{1}$ Fakultas Kedokteran dan Ilmu Kesehatan, Universitas Islam Negeri Maulana Malik Ibrahim, Malang, Indonesia
} penggunaan antibiotik,

Pascabedah

\begin{abstract}
INFO ARTIKEL
Sejarah artikel:

Penerimaan naskah: $31 \mathrm{Mei}$ 2020

Penerimaan naskah revisi: 23 Oktober 2020

Disetujui untuk dipublikasikan: 3 November 2020

Kata kunci :

Apendisitis akut, DDD/100 patientdays, DU 90\%, Ketepatan

\section{A B S T R A K}

Apendisitis akut adalah infeksi yang terjadi di apendiks vermiformis sehingga perlu segera dilakukan apendektomi. Apendektomi termasuk operasi kategori bersih kontaminasi yang memungkinkan terjadinya Infeksi Luka Operasi (ILO). Penggunaan antibiotik pada pasien pascabedah diharapkan untuk mencegah terjadinya infeksi tersebut. Penelitian ini bertujuan untuk mengidentifikasi profil penggunaan antibiotik dan mengetahui kuantitas serta kualitas penggunaan antibiotik. Penelitian ini menggunakan studi cross sectional yang dilakukan secara retrospektif menggunakan data rekam medis pasien pascabedah apendisitis akut Rumah Sakit Umum Daerah (RSUD) Kabupaten Pasuruan periode Januari-Desember 2018. Analisis data yang dilakukan pada penelitian ini secara deskriptif. Hasil dari penelitian ini menunjukkan bahwa profil penggunaan antibiotik terapeutik tertinggi untuk monoterapi adalah Sefuroksim $(25,81 \%)$ dan untuk terapi kombinasi adalah Fosfomisin + Metronidazol $(8,06 \%)$ dan Seftriakson + Metronidazol $(8,06 \%)$. Kuantitas penggunaan antibiotik menggunakan metode Anatomical Therapeutic Chemical/ Defined Daily Dose (ATC/DDD) diperoleh nilai DDD total 52,01 DDD/100 patient-days dengan antibiotik tertinggi Metronidazol rute parenteral 14,00 DDD/100 patient-days. Antibiotik yang masuk dalam segmen Drug Utilization (DU) $90 \%$ adalah (Metronidazol, Seftriakson, Fosfomisin, Sefuroksim, Gentamisin) dengan rute parenteral. Kualitas penggunaan antibiotik berdasarkan pedoman Infectious Disease Society of America (IDSA) tepat indikasi (11,86\%), tepat dosis $(52,54 \%)$, tepat interval $(22,03 \%)$, tepat lama pemberian $(28,81 \%)$ dan tepat rute $(96,61 \%)$.
\end{abstract}

\section{Evaluation of Antibiotics Use in Post-Surgical Acute Appendicitis Patients at ThePasuruan Regency General Hospital in 2018 (The Study Was Conducted atInpatient Installation of Pasuruan Regency General Hospital) \\ Keywords: \\ A B S T R A C T}

Acute

appendicitis, Appropriate of antibiotic use, DDD/100 patientdays, DU 90\%, Post surgery

\begin{abstract}
Acute appendicitis is an infection that occurs in vermiform appendix, and because of that it needs to do appendectomy immediately. Appendectomy is included in clean contaminated operation category which allows Surgical Site Infection (SSI). The antibiotics use in post-surgical patients to prevent the infections. The aims of this study to identify profile and determine the quantity and quality of antibiotics use. This study used cross sectional study with retrospective data on patient's medical records after surgery for acute appendicitis in General Hospital Pasuruan Regency on January-December 2018. Data analysis was performed descriptively. The result of this study showed that the highest profile of the antibiotic use for mono therapy was Cefuroxime (25.81\%) and for combination therapy were Phosphomycin + Metronidazole $(8.06 \%)$ and Ceftriaxone + Metronidazole $(8.06 \%)$. The quantity of antibiotics use by using Anatomical Therapeutic Chemical/Defined Daily Dose (ATC/DDD) method was obtained total DDD value 52.01 DDD/100 patient-days with the highest antibiotic was Metronidazole parenteral route 14.00 DDD/100 patient-days. Antibiotics included in Drug Utilization 90\% (DU 90\%) segment were (Metronidazole, Ceftriaxone, Phosphomycin, Cefuroxime, Gentamicin) by parenteral route. The quality of antibiotics use based on the Infectious Disease Society of America (IDSA) Guidelines, appropriate indication $(11.86 \%)$, appropriate dose $(52,54 \%)$, appropriate interval $(22,03 \%)$, appropriate route $(96.61 \%)$ and appropriate duration of treatment $(28.81 \%)$.
\end{abstract}

\footnotetext{
* Corresponding author: Wirda Anggraini, Jurusan Farmasi, Fakultas Kedokteran dan Ilmu Kesehatan, Universitas Islam Negeri Maulana Malik Ibrahim, Malang. E-mail:wirdaanggraini93@gmail.com.
} 


\section{Pendahuluan}

Apendisitis merupakan peradangan apendiks yang membahayakan jiwa jika tidak segera ditangani, terjadi infeksi berat yang dapat menyebabkan lumen usus pecah. ${ }^{1}$ Menurut data World Health Organization (WHO)tahun 2010 mortalitas akibat apendisitis di dunia mencapai 21.000 jiwa. $^{2}$ Kejadian apendisitis di Eropa tergolong tinggi sekitar $16 \%$ dibanding di Amerika sebanyak 7\%, Asia 4,8\% dan Afrika 2,6\% penduduk dari total populasi. ${ }^{3}$ Tingginya prevalensi di Eropa dan Amerika dipengaruhi oleh pola makan yang rendah serat. Sedangkan di Afrika dan Asia prevalensinya lebih rendah namun cenderung meningkat dikarenakan pola makan yang mengikuti orang barat. ${ }^{4}$ Prevalensi apendisitis di Indonesia pada tahun 2006, 2009, 2016, 2017 berturut-turut yaitu 28.949 pasien, 30.703 pasien, 65.755 pasien dan 75.601 pasien, hal ini menunjukkan adanya peningkatan jumlah pasien apendisitis dari tahun ke tahun. ${ }^{5,6,7}$ Kasus apendisitis disebutkan oleh Dinas Kesehatan (Dinkes) Jawa Timur tahun 2017 sebanyak 5.980 penderita dengan 177 penderita berakibat kematian.

Apendisitis menurut stadiumnya dibagi dua yaitu kronik dan akut. Apendisitis kronik dapat ditangani dengan pemberian terapi antibiotik sedangkan apendisitis akut perlu segera dilakukan pembedahan. Oleh karena itu penanganan apendisitis akut direkomendasikan dengan apendektomi yaitu operasi pengangkatan apendiks termasuk jenis operasi kategori bersih kontaminasi yang memungkinkan terjadinya Infeksi Luka Operasi (ILO). ${ }^{8}$ Berdasarkan hasil survei WHO dilaporkan bahwa prevalensi ILO di dunia berkisar 5\% - 15\%. National Nosocomial Infection Surveillace United States America menyebutkan bahwa ILO merupakan infeksi urutan ketiga tersering yang terjadi di rumah sakit sekitar $14 \%-16 \%$. Sementara prevalensi ILO di Indonesia sekitar 2,3\% $18,3 \%$. $^{9}$

Pencegahan kejadian ILO bagi pasien apendisitis akut yang akan menjalani apendektomi dapat diberikan antibiotik profilaksis. Kemudian bila saat operasi ditemukan perforasi maka pemberian antibiotik akan diperpanjang sebagai terapi antibiotik pascabedah.. ${ }^{5}$ Menurut Peraturan Menteri Kesehatan (Permenkes) RI tahun 2011 penggunaan antibiotik bijak yaitu penggunaan antibiotik dengan spektrum sempit, pada indikasi yang tepat, interval dan lama pemberian yang tepat serta dosis yang adekuat. Jika penggunaan antibiotik tidak tepat maka selain berisiko terjadinya infeksi berkelajutan juga dapat menyebabkan resistensi antibiotik sehingga berdampak pada bertambah lamanya rawat inap dan biaya pengobatan serta berisiko kecacatan dan kematian. ${ }^{10}$

Menurut Permenkes RI tahun 2011, untuk menilai penggunaan antibiotik dapat dilakukan evaluasi secara kuantitatif dan kualitatif. Evaluasi kuantitatif dilakukan menggunakan metode DDD sehingga dihasilkan nilai
DDD/100 patient-days. Hasil evaluasi penggunaan antibiotik ini penting karena berperan sebagai indikator mutu Program Pengendalian Resistensi Antibiotik (PPRA) yaitu meningkatnya ketepatan penggunaan antibiotik dan menurunnya jumlah konsumsi antibiotik. ${ }^{11}$ Berdasarkan penelitian yang dilakukan oleh Zulfikar (2014) tentang studi penggunaan antibiotik pada kasus bedah apendiks di instalasi rawat inap RSD dr. Soebandi Jember Tahun 2013 menunjukkan hasil bahwa penggunaan antibiotik pada pasien apendisitis sebesar $25 \%$ tidak tepat dosis. Hal tersebut menunjukkan pentingnya dilakukan evaluasi penggunaan antibiotik di rumah sakit lainnya khususnya RSUD Kabupaten Pasuruan apakah sudah tepat ataukah belum tepat.

Evaluasi kualitatif dilakukan dengan menilai beberapa kriteria antara lain tepat indikasi, tepat dosis, tepat interval, tepat lama pemberian dan tepat rute. ${ }^{11}$ Dengan demikian penelitian ini bertujuan untuk mengidentifikasi profil dan mengetahui kuantitas serta kualitas penggunaan antibiotik pada pasien pascabedah apendisitis akut di RSUD Kabupaten Pasuruan tahun 2018.

Alasan dipilihnya RSUD Kabupaten Pasuruan sebagai tempat penelitian karena rumah sakit tersebut merupakan rumah sakit milik pemerintah yang menjadi rujukan masyarakat di Kabupaten Pasuruan. RSUD tersebut juga memiliki program pengendalian resistensi antibiotik sehingga evaluasi penggunaan antibiotik penting dilakukan demi mendukung program tersebut.

\section{Metode}

Penelitian ini merupakan penelitian observasional dengan desain studi cross sectional secara retrospektif menggunakan data rekam medis pasien yang telah menjalani bedah apendisitis akut di instalasi rawat inap RSUD Kabupaten Pasuruan periode Januari-Desember 2018. Sampel dalam penelitian ini adalah semua data pasien yang telah menjalani bedah apendisitis akut yang memenuhi kriteria inklusi dan eksklusi. Kriteria inklusi dalam penelitian ini adalah rekam medis pasien pascabedah apendisitis akut yang mendapatkan terapi antibiotik dengan usia 18 tahun ke atas dan memiliki data lengkap yaitu nomor rekam medis, tanggal masuk dan keluar rumah sakit, tanggal operasi, diagnosis, usia, jenis kelamin, nama obat antibiotik, regimen dosis, rute, waktu dan lama pemberian antibotik. Kriteria eksklusi dalam penelitian ini adalah rekam medis pasien yang menjalani bedah apendisitis akut yang menderita infeksi lain, yang menyatakan pulang paksa, meninggal atau pindah rumah sakit lain.

Analisis data secara deskriptif berupa presentase profil penggunaan antibiotik monoterapi ataupun kombinasi, nilai DDD/100 patient-days antibiotik dan presentase ketepatan penggunaan antibiotik pada pasien pascabedah apendisitis akut dengan pedoman Infectious Disease Society of America (IDSA) Guidelines. Penelitian 
ini telah mendapatkan persetujuan laik etik dengan nomor 042/EC/KEPK-FKIK/2019 dari Komisi Etik Penelitian Kesehatan Fakultas Kedokteran dan Ilmu Kesehatan UIN Maulana Malik Ibrahim Malang.

\section{Hasil dan Diskusi}

Jumlah populasi dalam penelitian ini sebanyak 102 rekam medis yang menunjukkan bahwa pasien tersebut telah menjalani bedah apendisitis akut di RSUD Kabupaten Pasuruan tahun 2018. Dari populasi tersebut diperoleh sampel yang memenuhi kriteria inklusi sebanyak 59 rekam medis.

Tabel 1. Demografi pasien

\begin{tabular}{|c|c|c|}
\hline Variabel & Jumlah Pasien & Persentase $(\%)$ \\
\hline \multicolumn{3}{|l|}{ Jenis Kelamin } \\
\hline Laki-laki & 31 & 52,54 \\
\hline Perempuan & 28 & 47,46 \\
\hline Total & 59 & 100 \\
\hline \multicolumn{3}{|l|}{ Usia } \\
\hline $18-25$ tahun & 24 & 40,68 \\
\hline 26-35 tahun & 12 & 20,34 \\
\hline $36-45$ tahun & 14 & 23,73 \\
\hline 46-55 tahun & 5 & 8,48 \\
\hline $56-65$ tahun & 3 & 5,08 \\
\hline$>65$ tahun & 1 & 1,69 \\
\hline Total & 59 & 100 \\
\hline
\end{tabular}

Berdasarkan data demografi pasien pascabedah apendisitis akut di RSUD Kabuaten Pasuruan periode Januari-Desember 2018 diketahui bahwa pasien jenis kelamin laki-laki lebih banyak dibandingkan pasien jenis kelamin perempuan yakni sebanyak 31 pasien $(52,54 \%)$. Hal ini dikarenakan bahwa proporsi jaringan limfoid pada apendiks laki-laki lebih banyak dibandingkan perempuan sehingga laki-laki berisiko menderita apendisitis dua kali lipat dibandingkan perempuan. ${ }^{12}$ Selain itu, laki-laki lebih banyak menghabiskan waktu di luar rumah untuk bekerja dan cenderung untuk mengonsumsi makanan tidak sehat dan kurang berserat. ${ }^{13,14}$ Sedangkan menurut usia, jumlah pasien apendisitis akut tertinggi pada kelompok usia 18-25 tahun sebanyak 24 pasien $(40,68 \%)$.dan seiring bertambahnya usia akan mengalami penurunan jumlah pasien. Hal ini disebabkan pada usia 18-25 tahun terdapat perkembangan secara maksimal dari jaringan limfoid di apendiks sehingga menjadi faktor pemicu tersumbatnya apendiks, sumbatan yang sedikit saja dapat menyebabkan tekanan intraluminal tinggi sehingga dapat berujung apendisitis. ${ }^{15}$ Penurunan insiden apendisitis akut terjadi pada usia diatas 25 tahun dikarenakan jaringan limfoid di apendiks akan berkurang hingga setengahnya dan akan berkurang hingga menghilang setelah usia diatas 60 tahun. ${ }^{16}$

Tabel 2. Profil penggunaan antibiotik

\begin{tabular}{|c|l|c|c|}
\hline No. & \multicolumn{1}{|c|}{ Jenis Antibiotik } & $\begin{array}{c}\text { Jumlah } \\
\text { Pasien }\end{array}$ & $\begin{array}{c}\text { Persentase } \\
(\%)\end{array}$ \\
\hline \multicolumn{2}{|c|}{ Terapi Antibiotik Tunggal } \\
\hline 1 & Sefuroksim & 16 & 25,81 \\
\hline 2 & Fosfomisin & 12 & 19,35 \\
\hline 3 & Ampisilin-Sulbaktam & 8 & 12,90 \\
\hline 4 & Seftriakson & 4 & 6,45 \\
\hline 5 & Siprofloksasin & 2 & 3,23 \\
\hline 6 & Sefadroksil & 5 & 1,61 \\
\hline Terapi Antibiotik Kombinasi & 5 & 8,06 \\
\hline 7 & Fosfomisin + Metronidazol & 2 & 3,23 \\
\hline 8 & Seftriakson + Metronidazol & 2 & 3,23 \\
\hline 9 & Siprofloksasin + Metronidazol & 2 & 3,23 \\
\hline 10 & Sefuroksim + Metronidazol & 1 & 1,61 \\
\hline 11 & Sefuroksim + Gentamisin & 1 & 1,61 \\
\hline 12 & Sefiksim + Metronidazol & 1 & 1,61 \\
\hline 13 & Fosfomisin + Gentamisin & 100 \\
\hline 14 & Seftriakson + Gentamisin & & \\
\hline Total & & 52 & \\
\hline & & & 2 \\
\hline
\end{tabular}

Keterangan:

Terdapat 3 pasien yang menerima pergantian antibiotik:

1. pergantian antibiotik dari Sefuroksim ke Sefadroksil

2. pergantian antibiotik dari Siprofloksasin + Metronidazol ke Sefiksim + Metronidazol

3. pergantian antibiotik dari Sefuroksim + Metronidazol ke Fosfomisin + Gentamisin

Penggunaan antibiotik pada pasien pascabedah apendisitis akut pada Tabel 2 terbagi menjadi dua macam yaitu terapi antibiotik tunggal (monoterapi) dan terapi antibiotik kombinasi. Penggunaan terapi antibiotik tunggal terbanyak adalah Sefuroksim sebanyak 16 pasien $(25,81 \%)$. Sefuroksim merupakan antibiotik golongan Sefalosporin generasi dua yang memiliki spektrum lebih luas dari generasi pertama yaitu kurang aktif terhadap bakteri gram positif namun lebih aktif terhadap bakteri gram negatif. Mekanisme kerja antibiotik ini adalah sebagai bakterisida dengan menghambat sintesis mukopeptida pada dinding sel bakteri. ${ }^{17}$ Berdasarkan penelitian ini, Sefuroksim menjadi antibiotik terbanyak digunakan sebagai terapi antibiotik tunggal karena menurut Formularium RSUD Bangil (2019) Sefuroksim diindikasikan sebagai antibiotik yang direkomendasikan pada kasus bedah abdomen. Sedangkan penggunaan terapi 
antibiotik kombinasi terbanyak adalah Fosfomisin + Meronidazol dan Seftriakson + Metronidazol masingmasing sebanyak 5 pasien $(8,06 \%)$. Penggunaan antibiotik yang didominasi oleh kombinasi dengan Metronidazol dikarenakan Metronidazol adalah antimikroba yang memiliki aktivitas sangat baik terhadap bakteri anaerob. ${ }^{10}$ Hal ini didukung oleh hasil penelitian Zulfikar (2014) di RSD dr. Soebandi Jember pada kasus bedah apendiks yang menyatakan bahwa penggunaan antibiotik kombinasi dengan Metronidazol kemungkinan dengan alasan dikhawatirkan akan terjadi perforasi. Apendisitis dengan perforasi biasanya ditemukan bakteri anaerob sehingga diperlukan Metronidazol sebagai agen first line yang digunakan untuk mencakup bakteri tersebut.

Tabel 3. Perhitungan nilai DDD penggunaan antibiotik

\begin{tabular}{|c|c|c|c|c|c|c|c|}
\hline No & $\begin{array}{l}\text { Kode } \\
\text { ATC }\end{array}$ & $\begin{array}{c}\text { Jenis } \\
\text { Antibiotik }\end{array}$ & Rute & $\begin{array}{c}\text { DDD } \\
\text { Stand- } \\
\text { ar } \\
\text { WHO } \\
\text { (g) }\end{array}$ & $\begin{array}{c}\text { Jumlah } \\
\text { Antibio } \\
\text {-tik } \\
\text { yang } \\
\text { Diguna- } \\
\text { kan (g) }\end{array}$ & $\begin{array}{c}\sum_{\text {LO }} \\
\text { S } \\
\text { (ha } \\
\text { ri) }\end{array}$ & $\begin{array}{c}\text { DDD / } \\
100 \\
\text { patient } \\
\text {-days }\end{array}$ \\
\hline 1 & $\begin{array}{c}\text { J01XD } \\
01\end{array}$ & Metronidazol & $\mathrm{P}$ & 1,5 & 52,5 & \multirow{10}{*}{250} & 14,00 \\
\hline 2 & $\begin{array}{c}\text { J01DD } \\
04\end{array}$ & Seftriakson & $P$ & 2 & 50 & & 10,00 \\
\hline 3 & $\begin{array}{c}\text { J01XX } \\
01\end{array}$ & Fosfomisin & $\mathrm{P}$ & 8 & 188 & & 9,40 \\
\hline 4 & $\begin{array}{c}\text { J01DC } \\
02\end{array}$ & Sefuroksim & $\mathrm{P}$ & 3 & 66,5 & & 8,87 \\
\hline 5 & $\begin{array}{c}\mathrm{J} 01 \mathrm{~GB} \\
03\end{array}$ & Gentamisin & $\mathrm{P}$ & 0,24 & 2,08 & & 3,47 \\
\hline 6 & $\begin{array}{c}\mathrm{J} 01 \mathrm{M} \\
\mathrm{A} 02\end{array}$ & Siprofloksasin & $\mathrm{P}$ & 0,8 & 6 & & 3,00 \\
\hline 7 & $\begin{array}{c}\text { J01CR } \\
01\end{array}$ & $\begin{array}{l}\text { Ampisilin- } \\
\text { Sulbaktam }\end{array}$ & $\mathrm{P}$ & 6 & 40 & & 2,67 \\
\hline 8 & $\begin{array}{c}\text { J01DB } \\
05\end{array}$ & Sefadroksil & $\mathrm{O}$ & 2 & 1,5 & & 0,30 \\
\hline 9 & $\begin{array}{c}\text { J01DD } \\
08\end{array}$ & Sefiksim & $\mathrm{O}$ & 0,4 & 0,2 & & 0,20 \\
\hline 10 & $\begin{array}{c}\text { P01A } \\
\text { B01 }\end{array}$ & Metronidazol & $\mathrm{O}$ & 2 & 0,5 & & 0,10 \\
\hline \multicolumn{7}{|c|}{ Total } & 52,01 \\
\hline
\end{tabular}

Pada Tabel 3 dapat dilihat nilai DDD total dalam penelitian ini dengan total Length of Stay (LOS) 250 hari diperoleh sebesar 52,01 DDD/100 patient-days. Adapun antibiotik dengan nilai DDD tertinggi adalah Metronidazol rute parenteral yaitu 14,00 DDD/100 patient-days.

\begin{tabular}{|c|c|c|c|c|c|c|c|}
\hline $\begin{array}{l}\mathbf{N} \\
\mathbf{o}\end{array}$ & $\begin{array}{l}\text { Kode } \\
\text { ATC }\end{array}$ & $\begin{array}{c}\text { Jenis } \\
\text { Antibiotik }\end{array}$ & $\begin{array}{c}\text { Rut } \\
\text { e }\end{array}$ & $\begin{array}{c}\text { DDD / } \\
100 \\
\text { patient- } \\
\text { days }\end{array}$ & $\begin{array}{l}\text { DU } \\
(\%)\end{array}$ & $\begin{array}{c}\text { DU } \\
\text { Kumu } \\
\text { latif }\end{array}$ & $\begin{array}{l}\text { Segme } \\
\text { n DU }\end{array}$ \\
\hline 1 & $\begin{array}{l}\text { J01XD0 } \\
1\end{array}$ & Metronidazol & $P$ & 14,00 & 26,92 & 26,92 & \multirow{5}{*}{$90 \%$} \\
\hline 2 & $\begin{array}{l}\text { J01DD0 } \\
4 \\
\end{array}$ & Seftriakson & $P$ & 10,00 & 19,23 & 46,15 & \\
\hline 3 & $\begin{array}{l}\text { J01XX0 } \\
1\end{array}$ & Fosfomisin & $\mathrm{P}$ & 9,40 & 18,08 & 64,23 & \\
\hline 4 & $\begin{array}{l}\text { J01DC0 } \\
2\end{array}$ & Sefuroksim & $P$ & 8,87 & 17,05 & 81,28 & \\
\hline 5 & $\begin{array}{l}\text { J01GB0 } \\
3 \\
\end{array}$ & Gentamisin & $P$ & 3,47 & 6,67 & 87,95 & \\
\hline 6 & $\begin{array}{l}\text { J01MA } \\
02\end{array}$ & Siprofloksasin & $P$ & 3,00 & 5,77 & 93,71 & $10 \%$ \\
\hline
\end{tabular}

\begin{tabular}{|c|l|l|c|c|c|c|}
\cline { 7 - 7 } 7 & $\begin{array}{l}\text { J01CR0 } \\
1\end{array}$ & $\begin{array}{l}\text { Ampisilin- } \\
\text { Sulbaktam }\end{array}$ & $\mathrm{P}$ & 2,67 & 5,13 & 98,84 \\
\hline 8 & $\begin{array}{l}\text { J01DB0 } \\
5\end{array}$ & Sefadroksil & $\mathrm{O}$ & 0,30 & 0,58 & 99,42 \\
\hline 9 & $\begin{array}{l}\text { J01DD0 } \\
8\end{array}$ & Sefiksim & $\mathrm{O}$ & 0,20 & 0,38 & 99,80 \\
\hline 10 & $\begin{array}{l}\text { P01AB0 } \\
1\end{array}$ & Metronidazol & $\mathrm{O}$ & 0,10 & 0,19 & 100,00 \\
\hline
\end{tabular}

Profil DU 90\% menunjukkan bahwa terdapat antibiotik yang masuk dalam akumulasi $90 \%$ penggunaan. Pada Tabel 4 ditunjukkan bahwa antibiotik yang masuk ke dalam segmen DU $90 \%$ antara lainMetronidazol parenteral $(26,92 \%)$, Seftriakson parenteral $(19,23 \%)$, Fosfomisin parenteral $(18,08 \%)$, Sefuroksim parenteral $(17,05 \%)$, dan Gentamisin parenteral $(6,67 \%)$.

Evaluasi kuantitas penggunaan antibiotik menggunakan metode ATC/DDD diperoleh nilai DDD total dalam penelitian ini adalah 52,01 DDD/100 patientdays yang artinya terdapat 52 pasien mengonsumsi 1 DDD WHO antibiotik setiap harinya. Metronidazol dengan rute parenteral merupakan antibiotik dengan nilai DDD/100 patient-days tertinggi karena jika dikaitkan dengan profil penggunaan antibiotik menunjukkan bahwa Metronidazol adalah antibiotik yang sering digunakan sebagai terapi kombinasi kasus apendisitis. Sedangkan untuk antibiotik yang masuk ke dalam segmen DU 90\% menunujukkan bahwa perlu adanya kontrol terhadap penggunaan antibiotik tersebut karena banyaknya variasi jenis antibiotik yang masuk dalam segmen DU $90 \%$ menyebabkan rentannya insiden resistensi antibiotik dan meningkatnya peluang munculnya resistensi terhadap antibiotik yang digunakan. ${ }^{18}$ Salah satu cara untuk mencegah terjadinya resistensi adalah melakukan regulasi antibiotik untuk memastikan pemilihan antibiotik. ${ }^{19}$

Tabel 5. Evaluasi ketepatan penggunaan antibiotik

\begin{tabular}{|c|c|c|c|c|c|c|c|c|c|c|}
\hline \multirow{2}{*}{$\begin{array}{c}\text { Penilai } \\
\text { an }\end{array}$} & \multicolumn{2}{|c|}{$\begin{array}{c}\text { Tepat } \\
\text { Indikasi }\end{array}$} & \multicolumn{2}{|c|}{ Tepat Dosis } & \multicolumn{2}{|c|}{$\begin{array}{c}\text { Tepat } \\
\text { Interval }\end{array}$} & \multicolumn{2}{|c|}{$\begin{array}{l}\text { Tepat Lama } \\
\text { Pemberian }\end{array}$} & \multicolumn{2}{|c|}{ Tepat Rute } \\
\hline & $\mathbf{N}$ & $\%$ & $\mathbf{n}$ & $\%$ & $\mathbf{n}$ & $\%$ & $\mathbf{n}$ & $\%$ & $\mathbf{N}$ & $\%$ \\
\hline Tepat & 7 & $\begin{array}{c}11,8 \\
6\end{array}$ & 31 & $\begin{array}{l}52, \\
54\end{array}$ & 13 & $\begin{array}{l}22, \\
03\end{array}$ & 17 & $\begin{array}{c}28,8 \\
1\end{array}$ & 57 & $\begin{array}{l}96, \\
61\end{array}$ \\
\hline $\begin{array}{l}\text { Tidak } \\
\text { tepat }\end{array}$ & 52 & $\begin{array}{c}88,1 \\
4\end{array}$ & 28 & $\begin{array}{l}47, \\
46\end{array}$ & 46 & $\begin{array}{l}77, \\
97\end{array}$ & 42 & $\begin{array}{c}71,1 \\
9\end{array}$ & 2 & $\begin{array}{c}3,3 \\
9\end{array}$ \\
\hline Total & 59 & 100 & 59 & 100 & 59 & 100 & 59 & 100 & 59 & 100 \\
\hline
\end{tabular}

Ketepatan penggunaan antibiotik dievaluasi berdasarkan lima kriteria yaitu tepat indikasi, tepat dosis, tepat interval, tepat lama pemberian dan tepat rute yang dibandingkan dengan IDSA Guidelines. Hasil evaluasi ketepatan penggunaan antibiotik seperti pada tabel 5 ditunjukkan bahwa tepat indikasi $11,86 \%$, tepat dosis $52,54 \%$, tepat interval $25,42 \%$, tepat lama pemberian $28,81 \%$ dan tepat rute $96,61 \%$.

Evaluasi kualitas penggunaan antibiotik dilakukan dengan membandingkan data dari rekam medis pasien 
terhadap IDSA Guidelines, didapatkan tepat indikasi yang masih tergolong rendah, hal ini dikarenakan penggunaan antibiotik terhadap pasien pascabedah apendisitis akut menggunakan prinsip broad spectrum dan belum didasarkan pada pedoman IDSA Guidelinessehingga perlu melakukan evaluasi PPAB secara berkala dengan mempertimbangkan pola bakteri, pola resistensi dan ketersediaan antibiotik. ${ }^{20}$ Untuk ketidaktepatan dosis pada penelitian ini dikarenakan pemberian dosis lebih rendah dibanding dosis yang direkomendasikan. Penggunaan dengan dosis terlalu kecil atau sub terapeutik dapat menyebabkan infeksi tak kunjung sembuh dan dapat terjadi resistensi bakteri. ${ }^{5}$ Pada hasil penelitian ini tidak ada penggunaan antibiotik dengan dosis lebih tinggi dari yang direkomendasikan. Selanjutnya, ketidaktepatan interval dikarenakan frekuensi pemberian antibiotik yang kurang dan waktu pemberian antibiotik yang tidak sesuai dengan interval yang telah ditentukan misalnya tiap 4 jam, tiap 6 jam, tiap 8 jam, tiap 12 jam atau tiap 24 jam . Hal ini dipengaruhi oleh beban kerja masing-masing perawat pelaksana yang cukup berat karena jumlah pasien yang banyak sementara tindakan yang harus dilakukan terhadap pasien tersebut juga banyak akibatnya jadwal pemberian obat sedikit tergeser yang menjadikan lama pemberian obat tidak tepat interval. ${ }^{21}$ Faktor lain yang mempengaruhi ketidaktepatan interval yaitu kurangnya komunikasi dan kerjasama antara praktisi yang terlibat dalam hal penjadwalan pemberian obat pasien. ${ }^{22}$

Tepat lama pemberian pada penelitian ini jika didasarkan pada IDSA Guidelinesadalah 4-7 hari, ${ }^{23}$ namun masih banyak dijumpai yang kurang dari rentang tersebut. Hal ini dikarenakan penghentian pemberian antibiotik dapat dilakukan dengan kriteria antara lain tidak terjadi demam, terdapat tanda dan gejala peningkatan gerak normal sistem pencernaan, pengembalian fungsi usus, dan penurunan leukositosis. Disisi lain infeksi juga bisa disebabkan oleh keberadaan pasien di rumah sakit yang disebut sebagai infeksi nosokomial, maka terdapat pertimbangan yakni pasien yang sudah membaik disarankan untuk melanjutkan pengobatan secara rawat jalan sehingga pemberian antibiotik saat rawat inap telah berakhir. Ketepatan rute pada penelitian ini termasuk tinggi disebabkan pasien rawat inap telah mendapatkan antibiotik dengan rute parenteral, sesuai dengan indikasi apendisitis akut yang harus segera diatasi, namun beberapa pasien tidak tepat rute karena mendapatkan antibiotik oral pada hari terakhir pasien berada di rawat inap dan akan keluar dari rumah sakit. Berdasarkan pedoman IDSA Guidelines rute yang direkomendasikan untuk pemberian antibiotik terhadap pasien pascabedah apendisitis akut adalah rute parenteral sebab jika diberikan dengan rute oral relatif mudah diterima namun harus mempertimbangkan sifat fisikokima obat, keadaan saluran pencernaan pasien dan interaksi obat saat diabsorbsi dalam saluran pencernaan yang dapat berpengaruh pada bioavailabilitas antibiotik sehingga pemberian dengan rute oral tidak direkomendasikan.

Kesimpulan dari penelitian ini adalahpenggunaan antibiotik pada pasien pascabedah apendisitis akut di RSUD Kabupaten Pasuruan tahun 2018 terbagi menjadi dua macam yaitu monoterapi dengan pemakaian antibiotik tertinggi yaitu Sefuroksim $(25,81 \%)$ dan terapi kombinasi dengan pemakaian antibiotik tertinggi yaitu Fosfomisin + Metronidazol $(8,06 \%)$ dan Seftriakson + Metronidazol $(8,06 \%)$. Kuantitas penggunaan antibiotik menggunakan metode ATC/DDD diperoleh nilai DDD total sebesar 52,01 $\mathrm{DDD} / 100$ patient-days dengan antibiotik tertinggi Metronidazol rute parenteral sebesar 14,00 DDD/100 patient-days. Antibiotik yang masuk dalam segmen DU 90\% adalah antibiotik (Metronidazol, Seftriakson, Fosfomisin, Sefuroksim, Gentamisin) dengan rute parenteral. Kualitas penggunaan antibiotik berdasarkan IDSA Guidelines diperoleh hasil tepat indikasi $(11,86 \%)$, tepat dosis $(52,54 \%)$, tepat interval $(22,03 \%)$, tepat lama pemberian $(28,81 \%)$ dan tepat rute $(96,61 \%)$.

\section{Daftar Pustaka}

1. Indri UV, Karim D, Elita V.Hubungan Antara Nyeri, Kecemasan dan Lingkungan dengan Kualitas Tidur pada Pasien Post Operasi Apendisitis. Jurnal Online Mahasiswa Program Studi Ilmu Keperawatan.2014;1(2):1.

2. Faridah, VN.Penurunan Tingkat Nyeri Pasien Post Op Apendisitis dengan Tehnik Distraksi Nafas Ritmik. Surya.2015;7(2):68.

3. [WHO] World Health Organization. Definisi Sehat WHO. Tersedia dari: www.who.int.

4. Santacroce R, dan Craig, S.Appendicitis. Tersedia dari: http://www.emedicine.com.

5. Zulfikar, F. Studi Penggunaan Antibiotik pada Kasus Bedah Apendiks Di Instalasi Rawat Inap RSD Dr. Soebandi Jember Tahun 2013 (Skripsi). Jember: Fakultas Farmasi Universitas Jember; 2014.

6. [Depkes RI] Departemen Kesehatan Republik Indonesia. Profil Kesehatan Indonesia Tahun 2009. Jakarta: Depkes RI; 2010.

7. [Depkes RI] Departemen Kesehatan Republik Indonesia. Laporan Hasil Riset Kesehatan Dasar Indonesia Tahun 2017. Jakarta: Badan Penelitian dan Pengembangan Kesehatan Depkes RI; 2017.

8. Datuan, WA. Evaluasi Rasionalitas Penggunaan Antibiotik Profilaksis Operasi Apendisitis Akut Pasien Dewasa dan Geriatri di RS Bethesda Yogyakarta tahun 2015 (Skripsi). Yogyakarta: Fakultas Farmasi Universitas Sanata Dharma; 2017.

9. Muttaqien MI, Hamidy MY, Rustam RP.The Overview Surgical Site Infection of Pasca Caesarean Section at Arifin Achmad General Hospital of Riau Province 1 January - 31 December 2014 Period. Jom FK. 2016;3(1):2. 
10. Hidayatullah, RM Rendy. Efektivitas Antibiotik yang Digunakan pada Pasca Operasi Apendisitis di RUMKITAL dr. Mintohardjo Jakarta Pusat(Skripsi). Jakarta: Fakultas Kedokteran dan Ilmu Kesehatan. UIN Syarif Hidayatullah Jakarta;2014.

11. Menteri Kesehatan Republik Indonesia. Peraturan Menteri Kesehatan Nomor 2406 Tahun 2011 tentang Pedoman Umum Penggunaan Antibiotik. Jakarta: Menteri Kesehatan Republik Indonesia;2011.

12. Sjamsuhidajat, R dan Jong, DW. Buku Ajar Ilmu Bedah Edisi 3. Jakarta: EGC Penerbit Buku Kedokteran;2011.

13. Sirma, F. Faktor Resiko Kejadian Apendisitis di Rumah Sakit Umum Daerah Kab. Pangkep (Skripsi). Makassar: Stikes Nani Hasanuddin Makassar; 2012.

14. Muttaqin, A dan Sari, K. Asuhan Keperawatan Perioperatif. Jakarta: Salemba Medika;2011.

15. Lee, J. The Influence of Sex and Age on Appendicitis in Children and Young Adults (Thesis). London: Social Medicine Research Unit London Hospital;2009.

16. Sander, MA.Apendisitis Akut: Bagaimana Seharusnya Dokter Umum dan Perawat Dapat Mengenali Tanda dan gejala Lebih Dini Penyakit Ini? Ejounal UMM. 2011;2(1):16.

17. Pratiwi, RH.Mekanisme Pertahanan Bakteri Patogen terhadap Antibiotik. Jurnal Pro-Life. 2017;4(3):420.

18. Mahmudah F, Sumiwi SA, Hartini S. Studi Penggunaan Antibiotik Berdasarkan ATC/DDD dan DU 90\% di Bagian Bedah Digestif di Salah Satu Rumah Sakit di Bandung. Jurnal Farmasi Klinik Indonesia.2016;5(4):294.

19. Sholih MG, Muhtadi A, Saidah S. Rasionalitas Penggnaan Antibiotik di Salah Satu Rumah Sakit Umum di Bandung Tahun 2010. Jurnal Farmasi Klinik Indonesia.2015;4(1):68.

20. Vessal G, Namazi S, Davarpanah MA, Foroughinia F.Evaluation of Prophylactic Antibiotic Administration at The Surgical Ward of A Major Refferal Hospital, Islamic Republic of Iran; 2010.

21. Sakinah S, Wigati PA, Arso SP. Analisis Sasaran Keselamatan Pasien Dilihat dari Aspek Pelaksanaan Indentifikasi Pasien dan Keamanan Obat di RS Kepresidenan RSPAD Gatot Subroto Jaktara. Jurnal Kesehatan Masyarakat.2017;5(4):148.

22. Sarmalina S, Paryanti, Sonlimar M. Pengaruh Partisipasi Tenaga Teknis Kefarmasian dalam Menurunkan Angka Kejadian Medication Error di bangsal Penyakit Dalam RS RK Charitas Palembang. Majalah Kesehatan PharmaMedika. 2011;3(1):214215.

23. Solomkin JS, Mazuski JE, Bradley JS, Rodvold KA, Goldstein EJC, Baron EJ, O'neill PJ, Chow AW, Dellinger EP, Eachempati SR, Gorbach S, Hilfiker M, May AK, Nathens AB, Sawyer RG, dan Bartlett JG. Diagnosis and Management of Complicated Intra- abdominal Infection in Adults and Children: Guidelines by The Surgical Infection Society and The Infectious Diseases Society of America. Clinical Infectious Diseases. 2010;50(2):138-139 